\title{
Fluorescence and FTIR markers for different taxa of Gymnema drug complex from Maharashtra
}

\author{
Savita S. Rahangdale ${ }^{1^{*}}$ \& Sanjaykumar R. Rahangdale ${ }^{2}$ \\ ${ }^{1}$ Department of Botany, Hon. Balasaheb Jadhav College, Ale, Pune, Maharashtra, 412 411, India \\ ${ }^{2}$ Department of Botany, Annasaheb Waghire College, Otur, Pune, Maharashtra, 412 409, India \\ *Email: gauriyana@yahoo.co.in
}

\section{ARTICLE HISTORY \\ Received: 15 January 2020 \\ Accepted: 19 May 2020 \\ Published: 01 July 2020 \\ KEYWORDS \\ Gymnema cuspidatum; \\ G. latifolium; G. montanum; \\ G. sylvestre; drug; pharmacognosy; \\ standards; Madhunashini; Gudmar}

\begin{abstract}
Gymnema sylvestre known as Madhunashini / Gudmar and being commercially traded as a remedy of diabetes. The other taxa of this genus are also used as alternative drugs. The drug standards are available for the former species but not for the alternative taxa. In the present study, four taxa of Gudmar complex are evaluated to develop drug identification markers through fluorescence study and FTIR analysis. These markers are successful in distinguishing individual drug samples. The study will help to find out the purity of the samples and also for verification of drugs.
\end{abstract}

\section{Introduction}

India is one of the leading countries with a high number of people with Diabetes mellitus and it is estimated that around 57 million people will be suffering from the disorder by the year 2025 (1). The world estimate is about 415 million, i.e., one in eleven persons (2). The majority of the cases are associated with obesity and lifestyle. The prevalence of the disease is very high in India following China which has about 109 million peoples suffering from this disorder. To treat the people in large number quality resources and products are needed. Therefore, the major research work is being done on diabetes eradication or to control diabetes by using herbal medicine. Several plants are claimed to possess antidiabetic properties in the traditional system and used by tribal people as well as local inhabitants. Due to side effects of allopathic drugs on kidney functions, stomach tiredness, weight gain, risk of liver disorders, etc. herbal medicines are preferred for control of diabetes throughout the world. Of these Gymnema R. $\mathrm{Br}$. is an important plant genus in terms of therapeutic application and commonly called as Gudmar / Gulmar i.e., sugar killer. It consists of 14 species and two varieties in India (3). In Maharashtra, the genus is represented by five species viz., G. cuspidatum (Thub.)
Kuntze; G. latifolium Wall. ex Wight; G. montanum (Roxb.) Hook. f.; G. inodorum (Lour.) Decne. and G. sylvestre (Retz.) R. Br. ex Sm. Out of these G. sylvestre is well known medicinal plant having properties like lowering blood sugar, balancing insulin level and excellent remedy for weight loss. Similarly, very few references are also available for $G$. latifolium and $G$. montanum mentioning their use in ethnomedicine for curing the disease such as diabetes, obesity, liver disorders, gastrointestinal ailments, constipation, water retention and snakebite (4-6). However, no scientific work is done on G. cuspidatum and $G$. inodorum regarding any such activities. Our previous studies (7-8) reported the use of these species as alternative drugs under the name Gudmar against diabetes.

These species are locally used as medicinal plants as per availability of taxa and sold in local as well as national market. Due to anti-diabetic property, Gymnema is being exported in the form of dry extract as well as a crude drug (9). However, the efficacy of the drug is dependent upon the purity of plant material as a drug. Many times misidentification of medicinal plants or adulteration in drug sample leads to severe health problems (10-11) therefore, correct identification of the drug using some common

(C) Rahangdale \& Rahangdale (2020). This is an open-access article distributed under the terms of the Creative Commons Attribution License, which permits unrestricted use, distribution, and reproduction in any medium, provided the original author and source are credited (https://creativecommons.org/licenses/by/4.0/).

To cite this article: Rahangdale S S, Rahangdale S R. Fluorescence and FTIR markers for different taxa of Gymnema drug complex from Maharashtra. Plant Science Today 2020;7(3):333-340. https://doi.org/10.14719/pst.2020.7.3.731 
techniques is essential for therapeutic application. Pharmacognostic standards are available for $G$. sylvestre only, even though other taxa are used as alternative drugs, are not studied and considered as adulterants. This also leads to non-utilization of alternative drugs. Non- availability of markers for alternative drugs provides a lacuna for illicit trade of the important resources. Hence, a study was undertaken to develop identification markers by using Fluorescence analysis and Fourier Transform Infrared spectrophotometry (FTIR.).

Fluorescence is the phenomenon exhibited both under visible and UV light by various chemical constituents present in the plant material. Fluorescence is considered to be a very significant and reliable parameter of pharmacognostic evaluations (12). Recently FTIR (Fourier Transform Infrared spectrophotometry) has been applied to identify herbal drugs or herbal drug analysis. The measurements made by FTIR were accurate and reproducible. By using this technique, chemical constituents and its functional group identification become easy. Therefore, these are taken as one of the evaluation parameters for the present study.

\section{Materials and Methods}

Leaf materials of Gymnema sylvestre and allied species which are used as alternative drugs were collected from different localities of Maharashtra. During the present study authors were able to collect the materials of four taxa viz., G. cuspidatum, G. latifolium, $G$. montanum and $G$. sylvestre and used in the analysis (Fig. 1). The sample materials were tagged. Specimens (two - three) from each species with the flowers and /or fruits were processed for herbarium specimen preparation and identification. The identity confirmation of these species was done with the help of available literature (13-16) and herbarium specimens at different herbaria, especially Herbarium of Botanical Survey of India, Western Regional Centre, Pune (BSI). Authenticated specimens are deposited in Herbarium of Department of Botany, Balasaheb Jadhav Arts, Commerce and Science College, Ale. The recent nomenclature is applied as per POWO (17). Leaf materials after collection were cleaned and dried in the shade for two weeks. The materials were ground to a coarse powder by using a household electric blender and passed through sieve no. 25. The fine powder was subjected to analysis for fluorescence and FTIR.

\section{Fluorescence analysis}

Some components are prominent and actively show fluorescence under a visible range of light, whereas, characterized fluorescence is not observed in others. These components showed distinguished fluorescence in UV light. Hence, the behaviour of each leaf sample with different chemical reagents was observed under visible light, a short and a long wavelength of ultraviolet light. For the fluorescence observations following procedure was followed.

Crude drug sample $(0.5 \mathrm{gm})$ was taken in each (nine replicates) clean and dry test tubes of $15 \mathrm{ml}$ capacity. In each separate tube, $5 \mathrm{ml}$ of different organic solvents viz., distilled water, glacial acetic acid, 50\% sulphuric acid, nitric acid, $1 \mathrm{~N}$ hydrochloric acid, $5 \% \mathrm{FeCl}_{3}$, picric acid, $1 \mathrm{~N} \mathrm{NaOH}$ (aqueous) and $1 \mathrm{~N}$ alcoholic $\mathrm{NaOH}$ were added separately. Then, all the tubes were shaken and they were allowed to stand for about $30 \mathrm{~min}$ at room temperature. The solutions obtained were observed under the visible daylight and UV light of short-wavelength $(254 \mathrm{~nm})$ and UV light of long-wavelength $(365 \mathrm{~nm})$ for their characteristic fluorescent colour.

\section{Fourier Transform Infra-Red (FTIR) spectrometry}

The FTIR spectra are recorded by using Perkin-Elmer spectrometer Model 65. Measurement range was 400 $\mathrm{cm}^{-1}$ to $4000 \mathrm{~cm}^{-1}$ with a resolution of $4 \mathrm{~cm}^{-1}$. Conventional transmission mode using the $\mathrm{KBr}$ pellet method was applied. $\mathrm{KBr}$ pellet spectra were recorded from the sample (c. $2 \mathrm{mg}$ ) which was ground and mixed with dry $\mathrm{KBr}$ powder (c. $200 \mathrm{mg}$ ). Then the mixture was crushed in a mechanical mould to form a tablet with a diameter of $3 \mathrm{~mm}$. The IR light passes the pellet before it reaches the detector. For the characterization of compound class on the basis of prominent peaks in the spectrum, Spectrometric identification of organic compounds (18) and IR spectrum table and chart of Merck (19) were followed.

\section{Results and Discussion}

\section{Fluorescence analysis}

The activities of leaf drug sample with different chemical reagents and fluorescence characters of $G$. cuspidatum, G. montanum, $G$. latifolium and $G$. sylvestre were observed under visible light, short UV and long UV lights and analyzed characters are tabulated in Table 1.

The results of fluorescence analysis showed that leaf powder of $G$. montanum, $G$. latifolium and $G$. sylvestre treated with alcoholic $1 \mathrm{~N} \mathrm{NaOH}$ emitted fluorescent green colour under short UV light and $G$. cuspidatum with green colour. Leaf powders of $G$. cuspidatum and $G$. sylvestre showed fluorescent green colour in short UV light when treated with Picric acid. Leaf powder of $G$. cuspidatum when treated with Acetic acid shown a fluorescent green colour under short UV light, while shown only light brown colour under long UV light. Gymnema sylvestre sample, when treated with acetic acid, shown a fluorescent green colour under short as well as long-wavelength UV lights. The test of leaf powder with nitric acid + ammonia given fluorescent green colour under short UV light only by the sample of $G$. latifolium, while for others this test was negative. The treatment with alcoholic $\mathrm{NaOH}$ under long UV showed orange colour in the sample of $G$. sylvestre, while samples of other species showed only light brown colour.

On the basis of fluorescence analysis, it is evident that drugs of different taxa exhibit different fluorescence colour under short UV $(\lambda=254 \mathrm{~nm})$ and long UV ( $\lambda=365 \mathrm{~nm})$ wavelengths. It is possible to identify them easily on the basis of the present results. 

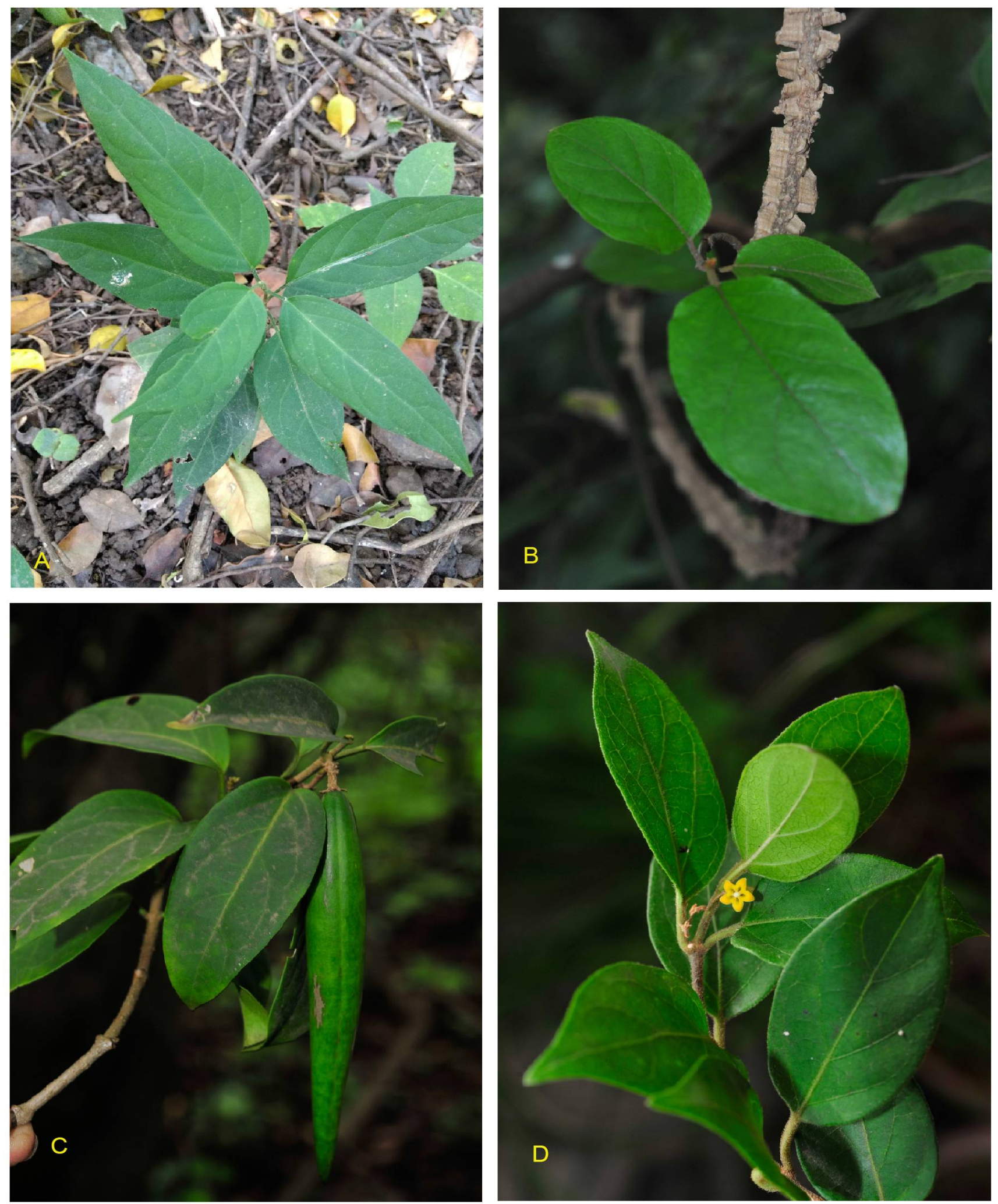

Fig. 1. Gymnema R. Br. species used in the study. A) G. cuspidatum (Thub.) Kuntze; B) G. latifolium Wall. ex Wight; C) G. montanum (Roxb.) Hook. f. and D) G. sylvestre (Retz.) R. Br. ex Sm.

An identification key is prepared for the powder samples of these taxa using fluorescence characters. While using the key, Table 1 can be referred. Other colours under UV exposure can also be useful as accessory parameters which support the identification e.g., development of orange colour under long UV for a mixture of G. sylvestre and $\mathrm{NaOH}$ (alchoholic).
Identification Key based on Fluorescence Analysis 1. Powder $+1 \mathrm{~N} \mathrm{NaOH}$ (alcoholic) $=$ No Florescent Green colour G. cuspidatum

1. Powder $+1 \mathrm{~N} \mathrm{NaOH}$ (alcoholic) $=$ Florescent Green colour under short UV 2

2. Powder + Nitric acid + Ammonia $=$ Florescent Green colour under short UV G. latifolium 
Table 1. Comparative fluorescence analysis for Gymnema species

\begin{tabular}{|c|c|c|c|c|c|c|c|c|c|c|c|c|c|}
\hline \multirow{2}{*}{$\begin{array}{l}\text { Sl. } \\
\text { No. }\end{array}$} & \multirow{2}{*}{ Experiment } & \multicolumn{4}{|c|}{ Visible /Daylight } & \multicolumn{4}{|l|}{ UV 254 nm } & \multicolumn{4}{|c|}{ UV 365 nm } \\
\hline & & Gc & Gl & Gm & GS & Gc & Gl & Gm & GS & Gc & Gl & Gm & GS \\
\hline 1 & Powder + DW & Green & Green & Green & Green & Black & Dark Green & Black & Green & $\begin{array}{l}\text { Dark } \\
\text { Green }\end{array}$ & Black & $\begin{array}{l}\text { Dark } \\
\text { Green }\end{array}$ & Light Green \\
\hline 2 & $\begin{array}{l}\begin{array}{l}\text { Powder + 1N } \\
\text { Sodium } \\
\text { hydroxide } \\
\text { (aqueous) }\end{array} \\
\end{array}$ & Green & $\begin{array}{l}\text { Yellow } \\
\text { Green }\end{array}$ & Green & $\begin{array}{l}\text { Brown } \\
\text { Yellow }\end{array}$ & Dark Green & Pale Green & Dark Green & Light Green & $\begin{array}{l}\text { Dark } \\
\text { Brown }\end{array}$ & Black & $\begin{array}{l}\text { Dark } \\
\text { Brown }\end{array}$ & Dark Green \\
\hline 3 & $\begin{array}{l}\text { Powder + 1N } \\
\text { Sodium } \\
\text { hydroxide } \\
\text { (alcohol) }\end{array}$ & $\begin{array}{l}\text { Light } \\
\text { Green }\end{array}$ & $\begin{array}{l}\text { Light } \\
\text { Green }\end{array}$ & $\begin{array}{l}\text { Light } \\
\text { Green }\end{array}$ & $\begin{array}{l}\text { Light } \\
\text { Yellow }\end{array}$ & Green & $\begin{array}{l}\text { Fluorescent } \\
\text { Green }\end{array}$ & $\begin{array}{l}\text { Fluorescent } \\
\text { Green }\end{array}$ & $\begin{array}{l}\text { Fluorescent } \\
\text { Green }\end{array}$ & $\begin{array}{l}\text { Light } \\
\text { Brown }\end{array}$ & $\begin{array}{l}\text { Light } \\
\text { Brown }\end{array}$ & $\begin{array}{l}\text { Light } \\
\text { Brown }\end{array}$ & Orange \\
\hline 4 & $\begin{array}{l}\text { Powder + 1N } \\
\text { Hydrochloric } \\
\text { acid }\end{array}$ & $\begin{array}{l}\text { Dark } \\
\text { Green }\end{array}$ & $\begin{array}{l}\text { Yellow } \\
\text { Green }\end{array}$ & $\begin{array}{l}\text { Dark } \\
\text { Green }\end{array}$ & Brown & Dark Green & Light Green & Dark Green & $\begin{array}{l}\text { Light } \\
\text { Brown }\end{array}$ & Brown & Greyish & Brown & Brown \\
\hline 5 & $\begin{array}{l}\text { Powder }+50 \% \\
\text { Sulphuric } \\
\text { acid }\end{array}$ & Black & Brown & Black & Brown & Dark Brown & $\begin{array}{l}\text { Dark } \\
\text { Green }\end{array}$ & $\begin{array}{l}\text { Dark } \\
\text { Brown }\end{array}$ & Light Blue & $\begin{array}{l}\text { Dark } \\
\text { Black }\end{array}$ & Black & $\begin{array}{l}\text { Dark } \\
\text { Brown }\end{array}$ & Light Green \\
\hline 6 & $\begin{array}{l}\text { Powder + } \\
\text { Nitric acid }\end{array}$ & $\begin{array}{l}\text { Light } \\
\text { Yellow } \\
\end{array}$ & $\begin{array}{l}\text { Light } \\
\text { Brown }\end{array}$ & $\begin{array}{l}\text { Light } \\
\text { Yellow } \\
\end{array}$ & $\begin{array}{l}\text { Reddish- } \\
\text { Brown }\end{array}$ & Light Green & Light Green & Light G & Light Green & $\begin{array}{l}\text { Light } \\
\text { Brown }\end{array}$ & $\begin{array}{l}\text { Dark } \\
\text { Brown }\end{array}$ & $\begin{array}{l}\text { Light } \\
\text { Brown }\end{array}$ & Light Green \\
\hline 7 & $\begin{array}{l}\text { Powder + } \\
\text { Picric acid }\end{array}$ & Yellow & $\begin{array}{l}\text { Dark } \\
\text { Yellow } \\
\end{array}$ & Yellow & Green & $\begin{array}{l}\text { Fluorescent } \\
\text { Green }\end{array}$ & Light Green & Green & $\begin{array}{l}\text { Fluorescent } \\
\text { Green }\end{array}$ & $\begin{array}{l}\text { Dark } \\
\text { Brown }\end{array}$ & Black & $\begin{array}{l}\text { Dark } \\
\text { Brown }\end{array}$ & Green \\
\hline 8 & $\begin{array}{l}\text { Powder }+ \\
\text { Acetic acid }\end{array}$ & $\begin{array}{l}\text { Light } \\
\text { Brown }\end{array}$ & $\begin{array}{l}\text { Pale } \\
\text { Green }\end{array}$ & $\begin{array}{l}\text { Light } \\
\text { Brown }\end{array}$ & Yellow & $\begin{array}{l}\text { Fluorescent } \\
\text { Green }\end{array}$ & Light Green & Green & $\begin{array}{l}\text { Fluorescent } \\
\text { Green }\end{array}$ & $\begin{array}{l}\text { Light } \\
\text { Brown }\end{array}$ & $\begin{array}{l}\text { Light } \\
\text { Brown }\end{array}$ & $\begin{array}{l}\text { Light } \\
\text { Brown }\end{array}$ & $\begin{array}{l}\text { Fluorescent } \\
\text { Green }\end{array}$ \\
\hline 9 & $\begin{array}{l}\text { Powder+ } \\
\text { Ferric } \\
\text { Chloride } \\
\end{array}$ & $\begin{array}{l}\text { Light } \\
\text { Brown }\end{array}$ & $\begin{array}{l}\text { Light } \\
\text { Brown }\end{array}$ & $\begin{array}{l}\text { Light } \\
\text { Brown }\end{array}$ & $\begin{array}{l}\text { Light } \\
\text { Brown }\end{array}$ & Dark Green & Light Green & Dark Green & Light Green & $\begin{array}{l}\text { Dark } \\
\text { Brown }\end{array}$ & $\begin{array}{l}\text { Dark } \\
\text { Black }\end{array}$ & $\begin{array}{l}\text { Dark } \\
\text { Brown }\end{array}$ & Green \\
\hline $\begin{array}{ll}101 \\
1 \\
1\end{array}$ & $\begin{array}{l}\text { Powder + } \\
\text { Nitric acid + } \\
\text { Ammonia }\end{array}$ & $\begin{array}{l}\text { Light } \\
\text { Brown }\end{array}$ & Brown & $\begin{array}{l}\text { Light } \\
\text { Brown }\end{array}$ & $\begin{array}{l}\text { Light } \\
\text { Brown }\end{array}$ & Light Green & $\begin{array}{l}\text { Fluorescent } \\
\text { Green }\end{array}$ & Light Green & Light Green & Brown & $\begin{array}{l}\text { Light } \\
\text { Brown }\end{array}$ & Brown & Pale Green \\
\hline
\end{tabular}

Where, $\mathrm{Gc}=$ G. cuspidatum; $\mathrm{Gl}=$ G. latifolium; $\mathrm{Gm}=$ G. montanum; $\mathrm{Gs}=$ G. sylvestre .

Table 2. Wave number $\left(\mathrm{cm}^{-1}\right)$ of dominant peak obtained from absorption spectra

\begin{tabular}{|c|c|c|c|c|c|c|c|}
\hline Functional Group & Appearance & Compound & $\begin{array}{c}\text { Peak Value / } \\
\text { Frequency range } \\
\left(\mathrm{cm}^{-1}\right)\end{array}$ & Gc & Gl & Gm & Gs \\
\hline $\mathrm{O}-\mathrm{H}$ stretching & Strong, broad & Alcohol & $3550-3200$ & 3291.79 & 3351.13 & 3359.44 & 3358.97 \\
\hline C-H stretching & Medium & Alkane & $3000-2840$ & 2922.92 & $\begin{array}{r}2919.74, \\
2851.43 \\
\end{array}$ & $\begin{array}{r}2920.10 \\
2851.02 \\
\end{array}$ & $\begin{array}{r}2920.54, \\
2851.40\end{array}$ \\
\hline $\mathrm{C}-\mathrm{H}$ bending & Weak & Aromatic Compound & $2000-1650$ & - & - & - & 1733.98 \\
\hline $\mathrm{C}=\mathrm{C}$ stretching & Strong & Alkene & $1648-1638$ & - & - & - & 1647.76 \\
\hline $\mathrm{C}=\mathrm{C}$ stretching & Medium & Alkene & $1662-1626$ & - & 1635.03 & 1626.17 & - \\
\hline $\mathrm{C}=\mathrm{C}$ stretching & Strong & $\begin{array}{l}\alpha, \beta \text { unsaturated } \\
\text { ketone }\end{array}$ & $1620-1610$ & 1616.61 & - & - & - \\
\hline $\begin{array}{l}\text { N-O asymmetric } \\
\text { stretch }\end{array}$ & Strong & Nitro compound & $1550-1475$ & - & - & 1519.50 & - \\
\hline C-C stretching & Medium & Aromatic & $1500-1400$ & - & - & 1446.87 & - \\
\hline O-H Bending & Medium & Phenol & $1390-1310$ & 1317.62 & $\begin{array}{l}\text { 1383.81, } \\
1317.38 \\
\end{array}$ & 1375.51 & $\begin{array}{r}1373.70, \\
1318.49 \\
\end{array}$ \\
\hline C-N stretching & Medium & Aliphatic amines & $1250-1020$ & 1243.55 & 1246.72 & 1244.27 & 1246.52 \\
\hline$S=0$ stretching & Strong & Sulfoxide & $1070-1030$ & 1036.05 & 1035.26 & 1065.24 & 1035.75 \\
\hline C-H Bending & Strong & 1,2,3- tridistributed & $780 \pm 20$ & - & 780.68 & - & - \\
\hline C-Br stretching & Strong & Halo compound & $690-515$ & & 618.23 & & \\
\hline C-I stretching & Strong & Halo compound & $600-500$ & 516.13 & 518.23 & 517.89 & 532.09 \\
\hline
\end{tabular}

Where, $\mathrm{Gc}=$ G. cuspidatum; $\mathrm{Gl}=$ G. latifolium; $\mathrm{Gm}=$ G. montanum; $\mathrm{Gs}=$ G. sylvestre .

2. Powder + Nitric acid + Ammonia $=$ No Florescent Green colour ............................................................ 3

3. Powder + Picric Acid / Acetic Acid = Florescent Green colour ............................................. G. sylvestre 3. Powder + Picric Acid / Acetic Acid = No Florescent Green colour ..... G. montanum

\section{FTIR Analysis}

FTIR spectrum was used to identify the functional groups of active components based on the peak value in the region of infra-red radiation. FTIR peak values for each species and functional groups are tabulated in Table 2. 
FTIR spectrum of leaf crude drug sample $G$. cuspidatum (Fig. 2) show characteristic peaks indicating different compound groups at $3291.79 \mathrm{~cm}^{-1}$ indicating O-H stretching of alcohol; $2922.92 \mathrm{~cm}^{-1} \mathrm{C}-\mathrm{H}$ stretching of alkanes; $1616.61 \mathrm{~cm}^{-1} \mathrm{C}=\mathrm{C}$ stretching of $\alpha$, $\beta$ unsaturated ketones; $1317.62 \mathrm{~cm}^{-1}$ O-H bending of phenol; $1243.55 \mathrm{~cm}^{-1} \quad$ C-N stretching of amine; $1036.05 \mathrm{~cm}^{-1} \mathrm{~S}=\mathrm{O}$ stretching of sulphoxide; and C-I stretching at $516.13 \mathrm{~cm}^{-1}$.

FTIR spectrum of leaf crude drug of G. latifolium (Fig. 3) show major peaks with characteristic compound class at $3351.13 \mathrm{~cm}^{-1}$ for $\mathrm{O}-\mathrm{H}$ stretching of alcohol; 2919.74 and $2851.43 \mathrm{~cm}^{-1}$ for C-H stretching of alkane; $1635.05 \mathrm{~cm}^{-1}$ for $\mathrm{C}=\mathrm{C}$ stretching of alkene; 1383.81 and $1317.38 \mathrm{~cm}^{-1}$ for $\mathrm{O}-\mathrm{H}$ bending of phenol; $1246.72 \mathrm{~cm}^{-1}$ for C-N stretching of amine; $1035.26 \mathrm{~cm}^{-1}$ for $\mathrm{S}=\mathrm{O}$ stretching of sulphoxide; $780.68 \mathrm{~cm}^{-1}$ for $1,2,3$ tridistributed $\mathrm{C}-\mathrm{H}$ bending; $618.23 \mathrm{~cm}^{-1}$ for $\mathrm{C}-\mathrm{Br}$ $\mathrm{cm}^{-1}$ for C-C stretching of aromatic compound; $1375.51 \mathrm{~cm}^{-1}$ for O-H bending of phenol; $1244.27 \mathrm{~cm}^{-1}$ for C-N stretching of amine; $1065.24 \mathrm{~cm}^{-1} \quad \mathrm{~S}=0$ stretching of sulphoxide; and C-I stretching at 517.89 $\mathrm{cm}^{-1}$.

FTIR spectrum of leaf crude drug of $G$. sylvestre (Fig. 5) indicates different compounds in the form of major peaks at $3358.97 \mathrm{~cm}^{-1}$ for $\mathrm{O}-\mathrm{H}$ stretching of alcohol; $2920.54 \mathrm{~cm}^{-1}$ and $2851.40 \mathrm{~cm}^{-1}$ for $\mathrm{C}-\mathrm{H}$ stretching of alkane; $1733.98 \mathrm{~cm}^{-1} \mathrm{C}-\mathrm{H}$ stretching of aromatic compound; $1647.76 \mathrm{~cm}^{-1}$ for $\mathrm{C}=\mathrm{C}$ stretching of alkene; $1373.70 \mathrm{~cm}^{-1}$ and $1318.49 \mathrm{~cm}^{-1}$ for $\mathrm{O}-\mathrm{H}$ bending of phenol; $1246.52 \mathrm{~cm}^{-1}$ for C-N stretching of amine; $1035.75 \mathrm{~cm}^{-1} \mathrm{~S}=\mathrm{O}$ stretching of sulphoxide; and $532.09 \mathrm{~cm}^{-1}$ for C-I stretching of halo compound.

The FTIR spectra of these four species show close relationships and similar components with each other. There were seven common absorbing

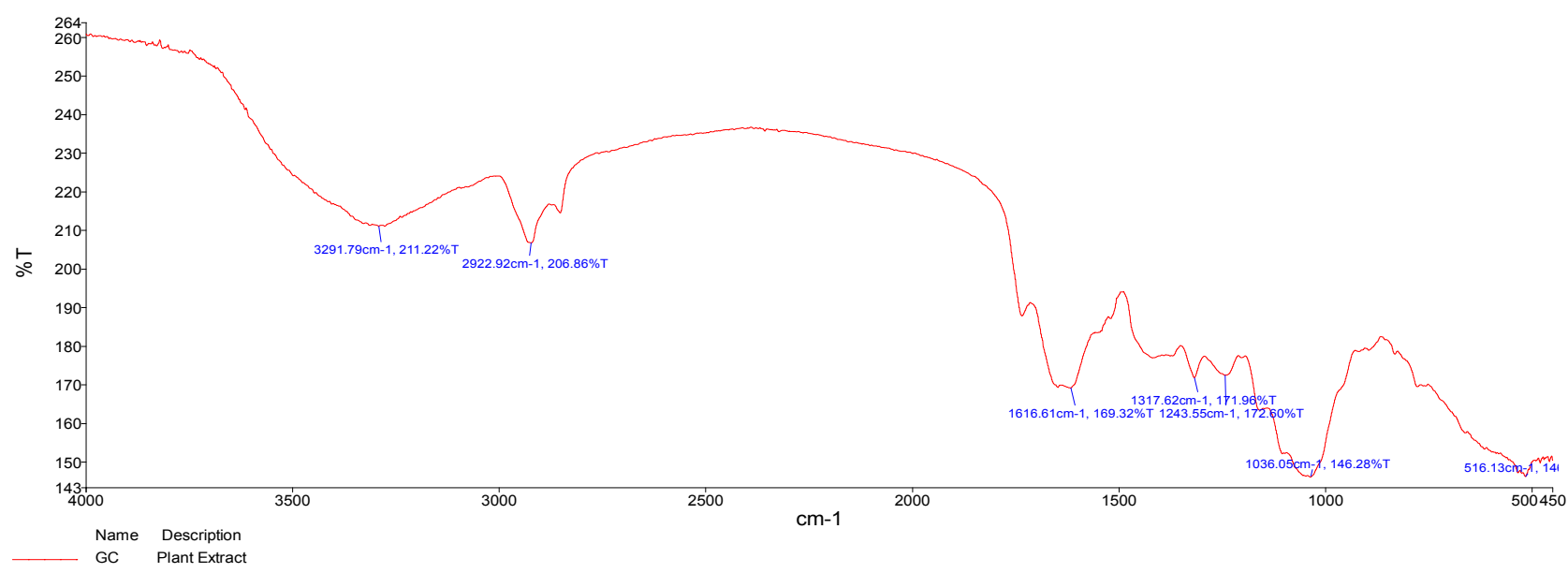

Fig. 2. FTIR spectrum of leaves of G. cuspidatum.

stretching and $518.62 \mathrm{~cm}^{-1}$ for C-I stretching.

The FTIR spectrum of leaves of G. montanum (Fig. 4) have characteristic peaks at $3359.44 \mathrm{~cm}^{-1}$ for $\mathrm{O}-\mathrm{H}$ stretching of alcohol; two peaks of C-H stretching of alkane at 2920.10 and $2851.02 \mathrm{~cm}^{-1}$; at $1626.17 \mathrm{~cm}^{-1}$ $\mathrm{C}=\mathrm{C}$ stretching of alkene; $1519.50 \mathrm{~cm}^{-1}$ for $\mathrm{N}-\mathrm{O}$ asymmetric stretching of nitro compound; 1446.87 peaks for $\mathrm{O}-\mathrm{H}, \mathrm{C}-\mathrm{H}, \mathrm{O}-\mathrm{H}$ phenol, $\mathrm{C}-\mathrm{N}, \mathrm{S}=\mathrm{O}$ and $\mathrm{C}-\mathrm{I}$ compound classes. Each of the species still bears its characters such as different peak shapes, numbers, position and intensity indicating different groups. The $\mathrm{C}-\mathrm{H}$ corresponding to aromatic compound group is present only in $G$. sylvestre. The peak for $\mathrm{C}=\mathrm{C}$ of alkene is present in

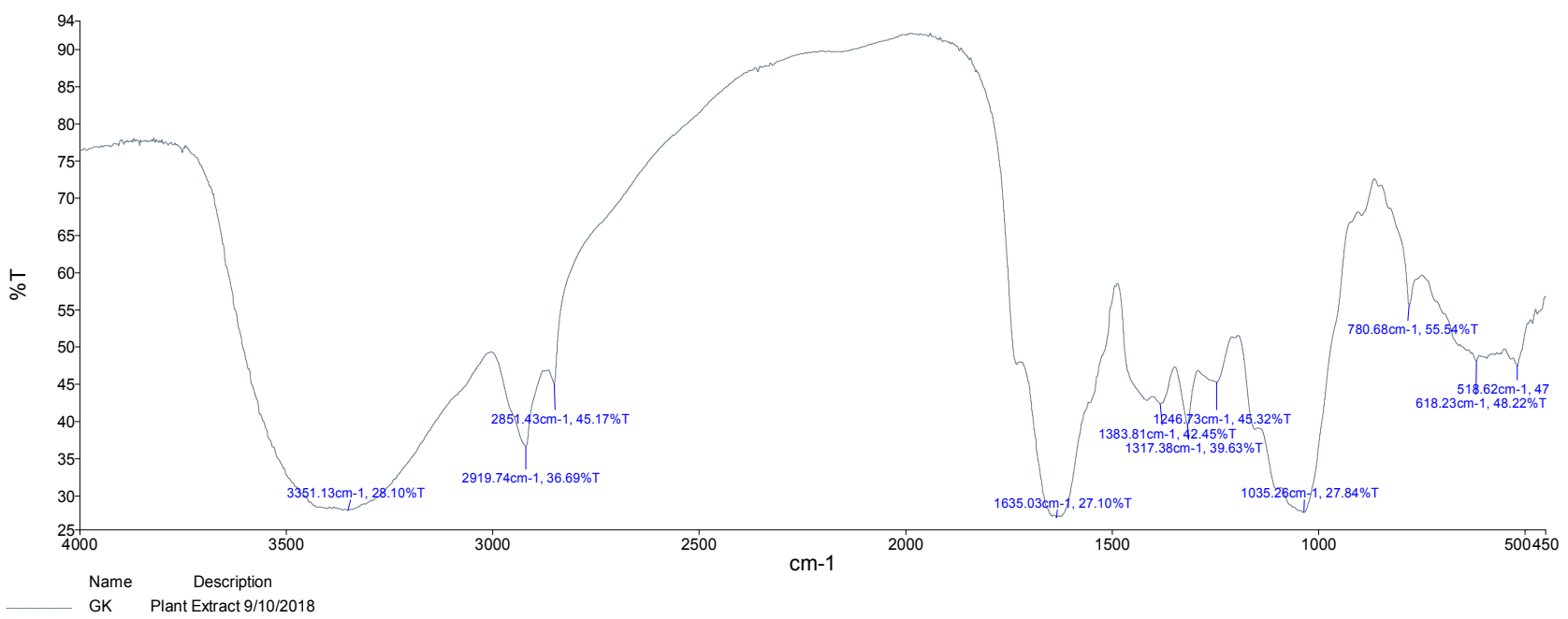

Fig. 3. FTIR spectrum of leaves of G. latifolium. 


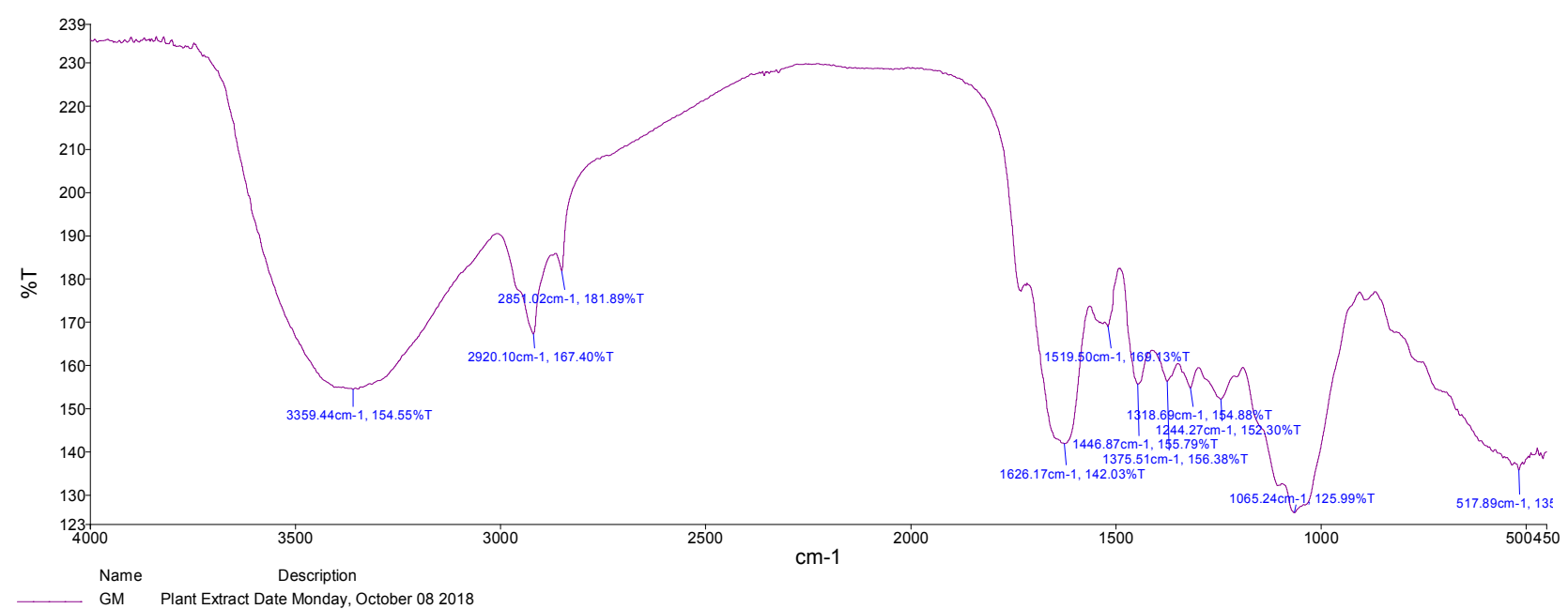

Fig. 4. FTIR spectrum of leaves of G. montanum.

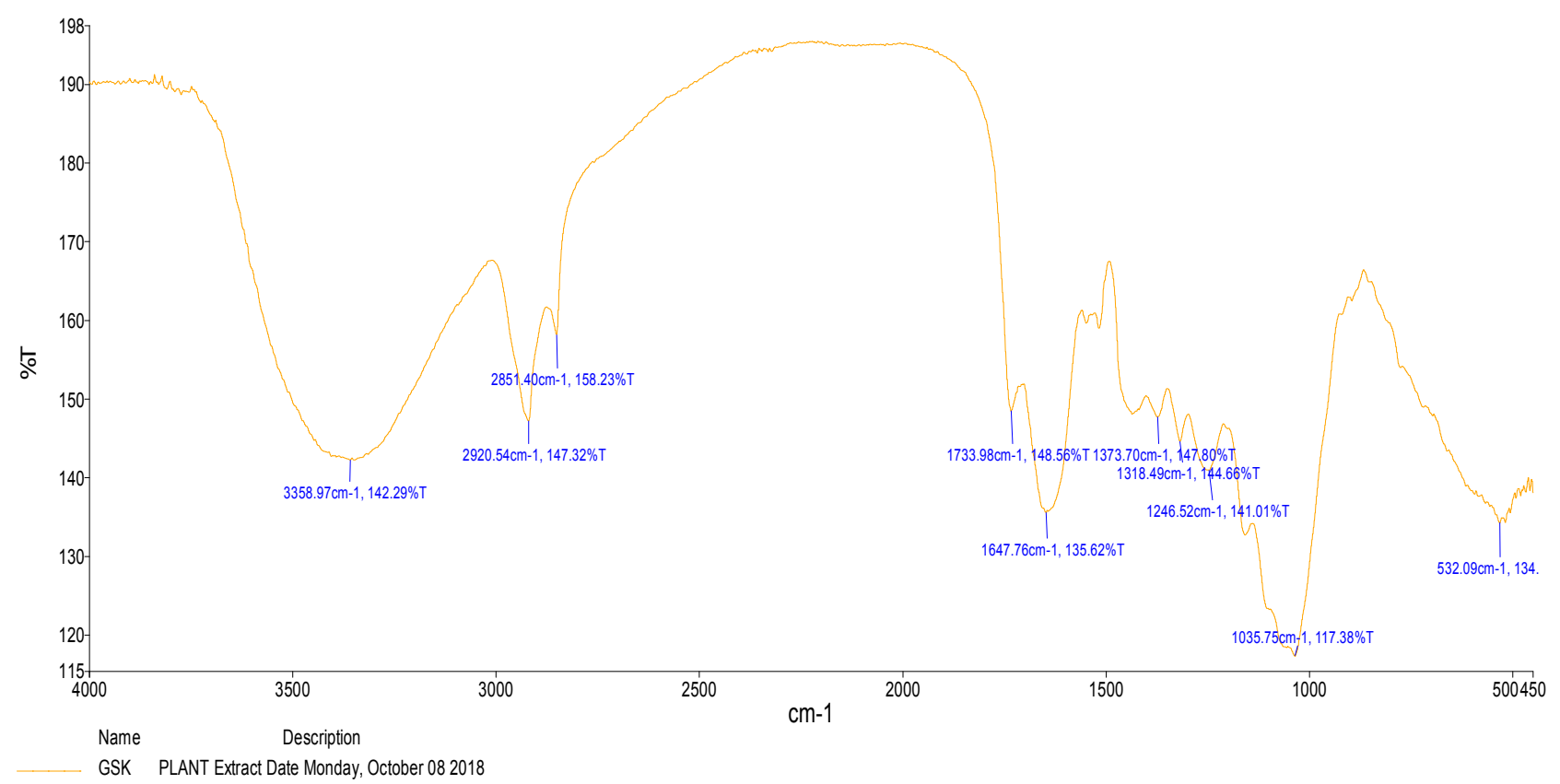

Fig. 5. FTIR spectrum of leaves of G. sylvestre.

all taxa except $G$. cuspidatum. The peak indicating $\mathrm{C}=\mathrm{C}$ stretching in $\alpha, \beta$ unsaturated ketone is unique to $G$. cuspidatum. The drug $G$. montanum has specific peak for $\mathrm{N}-\mathrm{O}$ asymmetric stretch of nitro compound. A characteristic peak for 1,2,3-tridistributed $\mathrm{C}-\mathrm{H}$ bending is present only in G. latifolium.

The results of present study in the form of fluorescence and FITR markers indicated clear differences among the taxa studied. Thus, considering all the evidences from the present study, the separation of drug samples become easy and any adulteration or blending of substitute / alternative drug could be easily identified with present Fluorescence and FTIR markers. Combined fluorescence markers and FTIR markers for each drug belonging to Gudmar complex are formulated on the basis of the present study. These markers for each drug are given below.

\section{Gymnema cuspidatum}

Fluorescence markers

i. Powder $+\mathrm{NaOH}$ (Alc.) $\rightarrow$ No fluorescence at any light.

ii. Powder + Picric acid / Acetic acid $\rightarrow$ Green Fluorescence under $254 \mathrm{~nm}$.

iii. Powder + Distilled Water $\rightarrow$ Black colour under $254 \mathrm{~nm}$.

FTIR markers

i. Absence of peak for C-H bending for aromatic compound.

ii. Absence of peak for $\mathrm{C}=\mathrm{C}$ for Alkene.

iii. Presence of $\mathrm{C}=\mathrm{C}$ strong stretching for $\alpha, \beta$ unsaturated ketone.

\section{Gymnema latifolium}

Fluorescence markers

i. Powder $+\mathrm{NaOH}$ (alc.) $\rightarrow$ Green fluorescence under $254 \mathrm{~nm}$. 
ii. Powder + Nitric acid + Ammonia $\rightarrow$ Green fluorescence under $254 \mathrm{~nm}$.

iii. Powder + Ferric chloride $\rightarrow$ Dark Black colour under $365 \mathrm{~nm}$.

iv. Powder $+\mathrm{NaOH}$ (aq.) $\rightarrow$ Black colour under $365 \mathrm{~nm}$.

FTIR markers

I. Unique peak for alkyl halides (C-Br stretching).

II. Peak for $\mathrm{N}-\mathrm{O}$ absent.

III. Presence of $\mathrm{C}=\mathrm{C}$ stretching for alkene.

IV. Unique peak for 1,2,3-tridistributed C-H bending present.

\section{Gymnema montanum}

Fluorescence markers

I. Powder $+\mathrm{NaOH}$ (alc.) $\rightarrow$ Green fluorescence under $254 \mathrm{~nm}$.

II. Powder $+50 \%$ Sulfuric acid $\rightarrow$ Dark Brown colour under $254 \mathrm{~nm}$ and $365 \mathrm{~nm}$.

FTIR markers

i. Absence of weak peak of aromatic compound group.

ii. Presence of $\mathrm{N}-\mathrm{O}$ asymmetric stretch of nitro compound.

iii. Presence of unique C-C stretching peak of aromatic compound.

\section{Gymnema sylvestre}

\section{Fluorescence markers}

i. $\quad$ Powder $+\mathrm{NaOH}$ (alc.) $\rightarrow$ Green fluorescence under $254 \mathrm{~nm}$ and orange colour under 365 $\mathrm{nm}$.

ii. Powder + Picric acid $\rightarrow$ Green fluorescence under $254 \mathrm{~nm}$.

iii. Powder + acetic acid $\rightarrow$ Green fluorescence under $365 \mathrm{~nm}$.

iv. Powder $+50 \%$ Sulfuric acid $\rightarrow$ Light blue colour under $254 \mathrm{~nm}$.

\section{FTIR markers}

i. Nitro compounds and unsaturated ketones absent.

ii. Peak for C-I stretching present.

iii. Presence of peak for $\mathrm{C}-\mathrm{H}$ bending of aromatic compound.

iv. Peak for C-C stretch of aromatic compound absent.

\section{Conclusion}

The results of the present study provide significant outcomes in the form of Fluorescence and FTIR markers for four taxa used under Gudmar complex. These markers are of immense importance for the quality assurance of the crude drug samples because any impurity or use of alternative drugs can be identified. The study also help in use of alternative drugs and assuring purity of drug in the trade. This is a cheaper and faster technique for the verification of the drug samples of Gymnema complex.

\section{Acknowledgements}

The authors are thankful to Principal of Sharadchandra Pawar Pharmacy College, Dumbarwadi for providing some facilities and help in phytochemical analysis and authorities of Vishal Junnar Institute of Pharmacy and Research, Ale for providing FTIR analysis. The first author (SSR) is grateful to the Savitribai Phule, Pune University, Pune for financial support. Thanks are due to the Principals of respective institutions of authors for support towards collaborative studies.

\section{Authors' contributions}

Savita S. Rahangdale (SSR) has done the analytical work of this study and presentation of the results and discussion. Sanjaykumar R. Rahangdale (SRR) has done the field work, collection and processing of samples, morphological characterization of the taxa and manuscript editing. The work is done on a mutual benefit basis.

\section{Competing interest statement}

Authors do not have any competing interests among them as well as any other persons with respect to this study.

\section{References}

1. Aravind K, Pradeepa R, Deepa R. Diabetes and coronary artery disease. Ind J Med Res. 2002;116:163-76

2. IDF. International Diabetes Federation [Internet]. IDF online; 2019 December 30. Available from: www.diabetes.co.uk/diabetes-prevalence.html

3. Karthikeyan S, Sanjappa M, Moorthy S. Flowering plants of In dia: Dicotyledons (Acanthaceae - Avicenniaceae). pp. 170-71. Kolkata: Botanical Survey of India; 2009

4. Chattopadhyay RR. Possible mechanism of antihyperglycemic effect of Gymnema sylvestre leaf extract. Gene Pharm. 1998;31:495-96. https://doi.org/10.1016/S0306-3623(97)00450-3

5. Rana TS, Sing KK, Rao RR. Some interesting reports on indigenous herbal remedies for Diabetes mellitus from India. In Fourth International Congress on Ethnobiology; NBRI, Lucknow; pp. 47.1994

6. Persaud SJ, Raman Al-Majed H, Jones PM. Gymnema sylvestre stimulates insulin release in vitro by increased membrane permeability. J of Endocri. 1999;163(2):207-12. https://doi.org/ 10.1677/joe.0.1630207

7. Rahangdale SS. Development of Pharmacognostic standards for Gudmar complex from Maharashtra. [project report]. Savitribai Phule, Pune University, Pune; pp. 105.2019

8. Rahangdale SS, Rahangdale SR. Digitized inventory of medicinal plant resources of Maharashtra. [project report]. Agharkar Research Institute, Pune; pp. 164.2013

9. Infodrive India. Gymnema export data 2015 [Internet]. Online; 2019 April 16. Available from: www.infodiveindia,com/india.export.data.gymnema-export-data.aspx

10. Johanns ES, Vander Kolk, Van Gemert, HM Sijben AE, Peters PW, De Vries I. An enemic of epileptic seizures after consumption of herbal tea. Netherland Tijdscrift Geneeskunde 2002;146(17):813-16

11. Phua DH, Cham G, Seow E. Two instances of Chinese herbal medicine poisoning in Singapore. Singapore Med J. 2008;49(5):131-33 
12. Gupta MK. Pharmacognostical evaluation of Grewia asiatica. Internat. J Plant Sci. 2006;1(2):249-51

13. Cooke T. The Flora of the Presidency of Bombay. London, Vol. II. (BSI Calcutta, Vol. I-III. Reprint 1958); pp. 207-45.1903. https://doi.org/10.5962/bhl.title.10884

14. Hooker JD. Flora of British India. Vol. IV; pp.1-78. (London): Oxford; 1885

15. Jagtap AP, Singh NP. Asclepiadaceae \& Periplocaceae, Fascicles of Flora of India 24, pp.332. Calcutta: Botanical Survey of India; 1999

16. Singh NP, Lakshminarasimhan P, Karthikeyan S, Prasanna PV, editors. Flora of Maharashtra State, Dicotyledons Vol II. pp. 336-64. Calcutta: Botanical Survey of India; 2001
17. POWO. Plants of the world online. [Internet]. 2020 May 12 Available from: http://www.plantsoftheworldonline.org/taxon

18. Silverstein RM, Webster FX. Spectrometric identification of organic compounds. $6^{\text {th }}$ ed. pp. 71-79. New York: John Wiley \& Sons, Ic; 1996

19. Merck. IR spectrum table and chart. [Internet] Sigmaaldrich online; 2020 May 13. Available from http://www,sigmaaldrich.com/technical-documents/articles/biology/ir-spectrumtable.html 